\title{
Government Ecology and the Indigenous Religion of the Suku Anak Dalam: Intersubjective Relations in Forest Conservation in Jambi, Indonesia
}

\author{
Khairun Najib \\ Department of Governmental Studies, UIN Sulthan Thaha Saifuddin, Jl. Lintas Jambi-Muara Bulian KM.16, \\ Simpang Sei Duren, Jambi, Indonesia 36361
}

Received July 1, 2020/Accepted November 23, 2020

\begin{abstract}
Integrating customary-religious values of an indigenous tribe "Suku Anak Dalam" (SAD) and state zoning system in Bukit Duabelas National Park (TNBD), Jambi, Indonesia is a configuration of an intersubjective relationship between government ecology and the religion of indigenous SAD in forest conservation that has not been studied by previous researchers. Hence, this article discusses that intersubjective relationship practice in preserving, maintaining, and protecting sustainable forest by assimilating the SAD's customary-religious values and the state zoning system. Moreover, this article also complements the shortcomings of previous researchers who believe that SAD's cosmology is animistic and proves that the TNBD zoning system's implementation as a cause of the SAD conflict. After conducting the interviews and the observations supported by relevant literature sources, this article shows that the SAD believes that the cosmos is not only inhabited by humans, but there are nonhuman beings such as animals and Badewo who are perceived as a human in which they are believed as social actors in forest conservation. SAD and nonhuman beings live together and contribute to each other and have a mutual relationship to life sustainability in the forest or so-called indigenous religion. Besides, the article also found that the TNBD zoning system is not the primary cause of the SAD conflict, rather the dynamics process in integrating state zoning and indigenous custom-religious spaces between the TNBD offices and the SAD.
\end{abstract}

Keywords: indigenous religion, Suku Anak Dalam, government ecology, intersubjective relations, forest conservation

*Correspondence author, email: khairunnajib@uinjambi.ac.id

\section{Introduction}

The indigenous people of Jambi or the Suku Anak Dalam (SAD) is a group of natives who speak the upstream Old Malay language of Jambi (Prasetijo, 2017a, 2017b) and inhabit Jambi's inland rainforests (Masy'ud et al., 2020). The SAD has a habit of hunting, gathering, and swarming, and they are nomadic (Andaya, 2001). Some scholars identify the SAD as Austro-Asia. Previous researchers (Andaya, 2002; Anderbeck, 2003; Sager, 2008; Mailinar \& Nurdin, 2013; Prasetijo, 2013; Berta, 2014; Japarudin, 2014; Takiddin, 2014; Prasetijo, 2015; Tylor, 2016; Prasetijo, 2017a, 2017b; Sager, 2017; Tremlett et al., 2017) have misunderstood the SAD's cosmology as animistic by indicating it through their belief in ancestral spirits. The SAD's belief is not animism. They perceive that nature is not only inhabited by humans, but also nonhuman beings (Hunt, 2005; Maarif, 2015; Shoko, 2016), such as soil, trees, animals, and Badewo, creatures that are understood to resemble humans and believed to function as social actors in the preservation, conservation, and protection of sustainable forests. Both the SAD and the nonhuman beings co-exist, share spaces, contribute to one another, and depend on each other. They also have a reciprocal relationship in the sustainability of livelihoods in the forest (Wright, 2012; Maarif, 2015). Furthermore, the
SAD's perception and beliefs criticize the arguments identifying beings as mere humans (Adansikou et al., 2017; Bird-David, 2017; Montgomery, 2019; Singh et al., 2020).

Therefore, in the practice of government ecology intersubjective relations and the SAD's indigenous religion in forest conservation, there will be a mutually beneficial relationship (Rossano, 2010; Peterson, 2012; Astor-Aguilera \& Harvey, 2018). This is because the re-zonation of the TNBD is an embodiment of the reciprocal relations of government ecology (Childs \& Hicks, 2019; Healy, 2019; Moeliono et al., 2017; Wasistiono, 2013; West, 2016) and the SAD's indigenous religion in integrating state zonation with customary/religious spaces. It is because the two aspects have the same basic conception, which is to form a mutually beneficial reciprocal relationship (Figure 1), creating intersubjective relations in the preservation, conservation, and protection of sustainable forests. Therefore, this article argues that the intersubjective relationship between government ecology and the customary-religious of the SAD in forest conservation is not only useful for the customary-religious of the SAD but also appears as a solution of sustainable forest preservation, maintenance, and protection as well as a beginning of the civilization transformation of forest management based on 


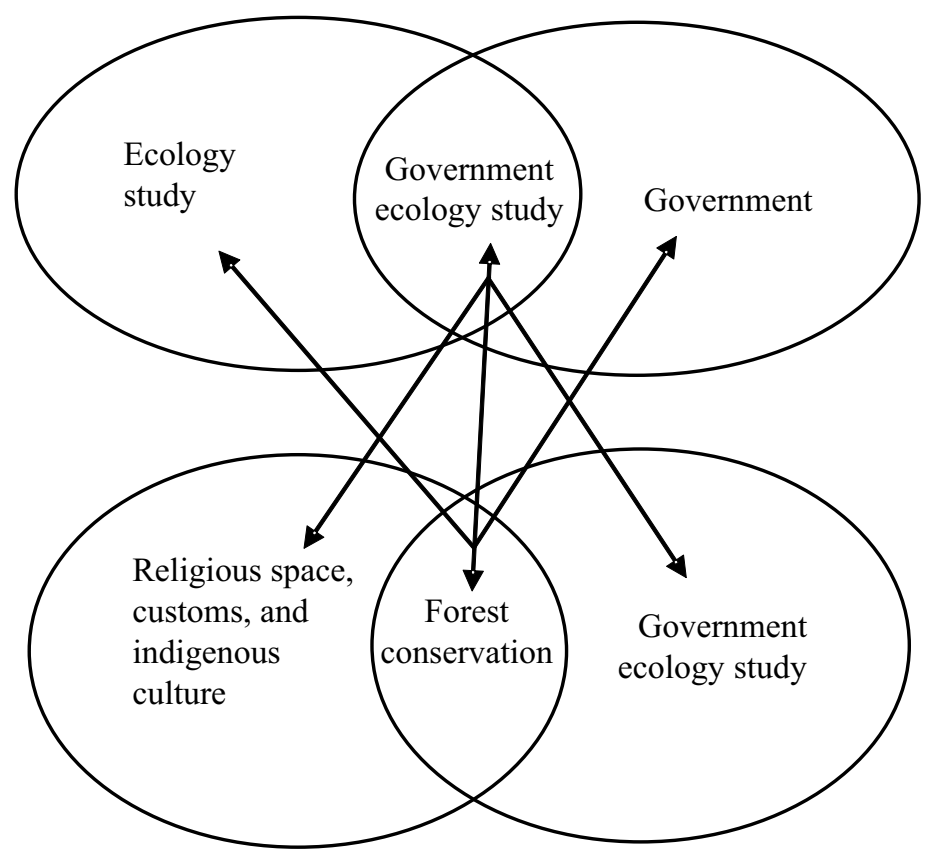

Source: Wasistiono (2013) and processed and added from various sources

Figure 1 Intersubjective relations of government ecology and indigenous religion.

indigenous people.

In order to analyze the above argumentation, this article discusses three essential research questions. First, what is the intersubjective relationship between government ecology and the customary-religious of the SAD?; Second, what is the dynamic of integrating state zonation with customaryreligious spaces of the SAD?; Third, how is the practice of government ecology and customary-religious of the SAD in forest conservation?

\section{Methods}

This research was conducted in Bukit Duabelas National Park, Sarolangun, Jambi. This article applied a qualitative method as the research approach. The primary data were collected through interviews and direct observation of the research (Flick, 2014; Olson et al., 2016; Shoko, 2016; Smith $\&$ Sparkes, 2016). Meanwhile, the secondary data were obtained from previous research results such as journals, bulletins, books, laws and regulations documents, internet, research reports, documents, and other supporting data sources. In collecting the data, the informants were predetermined from major people, like Jenang, SAD Temenggungs (tribal chief) in the TNBD, and Bukit Duabelas National Park Office.

Those informants were determined based on some criteria, i.e. 1) jenang is an authority and a symbol of the highest customary law and the highest leader (king) in the organizational structure of SAD's Kejenangan ancestral customary law governance, 2) temenggungs (tribal chief) is a community member in the forest who knows technically about SAD's customary-religious spaces, and 3) the national parks office is the state representative who has position as regulator and becomes a technical executor in integrating state zonation with SAD's traditional-religious spaces.

Thus, after collecting the primary and secondary sources, the data were processed using coding analysis techniques (Wicks, 2017). This technique was employed to qualify the information that had been obtained and to find valid information (Saldaña, 2013; Charmaz, 2014; Wicks, 2017). The results of this data coding were described to answer the research questions in the introduction.

\section{Results and Discussion}

Intersubjective relations: Indigenous religion and government ecology To answer the research question, this article uses an intersubjective relations theory. This theory was previously popularized by Gabriel Honoré Marcel, a $20^{\text {th }}$-century French philosopher, in his book Mystère de L'être. According to him, intersubjective is the existence of humans as living beings, in essence, identical to other creatures (esse est co-esse) (Marcel, 1950; Marcel \& Hanley, 2004; Marcel, 2007) which has a form of partnership relations beyond objective boundaries between two or more subjects that are interested in establishing certainties (Fricke \& Føllesdal, 2012; Benjamin, 2013; Tymieniecka, 2014; Benjamin, 2017; Husserl, 2019). Besides, intersubjective relations are also anti-egoism to create loyalty between people to share. Human existence is dedicated only to humans or other creatures, and vice versa. Other creatures and humans are equal (Benjamin, 2013; 2017).

Then, how are intersubjective relations between government ecology and the SAD's indigenous religion in 
the TNBD forest conservation-related? Before answering this question, it is necessary to first explain about the SAD's indigenous religious cosmology. As stated in the introduction, the SAD believes that humans and nonhuman beings inhabit the world. The SAD also perceive humans to have a sense of sharing and are dependent on other creatures such as forests, land, trees, animals, and Badewo.

In addition, the SAD also believes the sharing attitude is the only way to see God, with bersale, which is conceptualized as a social-religious relationship (Diamond, 1960; Goldstein, 1962). The SAD actualizes the relationship in their everyday lives, such as absorbing nonhuman beings' behaviors, such as linking birds' tweets to a sign of petako (calamities), or other natural disasters, as well as for instructions from ancestors that are obtained through dreams. This method is often found in people who have the habits of hunting, gathering, and swarming. They believe that there are intersubjective relations with other creatures in conserving and protecting the forest (Rossano, 2010; Atran, 2011; Bird-David, 2017; Astor-Aguilera \& Harvey, 2018).

Therefore, it should not be astounding if the SAD categorize Badewo as a species of nonhuman creatures that have the nature of sharing. Badewo is believed always to inhabit part of the indigenous forest landscapes and religion, which are called Tano Badewo and Tano Suban/Tano Tempelanai. The religious spatial structure is believed by the SAD to have a contribution in sharing the power of preserving and re-creating life in the forest, enabling Badewo and the SAD to protect each other in religious practices. Badewo is also considered an actor in socio-religious relations that mutually protect the TNBD forest biodiversity.

We and the Tiger Badewo, the Pangolin Badewo, the Elephant Badewo, the Cat Badewo, the Huluaye Badewo, the Honey Badewo, the Disease Badewo, and the Rice Badewo share with and look after each other. Through bedekir, we ask Badewo to protect us, and vice versa, we protect Badewo by obeying and following their orders and prohibitions such as mencerak telor, which is marrying a biological child, menikam gumi (marrying a biological mother), mandi di pancuran gading (marrying a sibling), and melebung dalam (cheating with someone's wife) (interview with Jenang Jalal, Temenggung Ngerip and Meladang, 26 November 2019).

Besides the SAD, such methods are also found in people who have the habits of hunting, gathering, and swarming, who believe that there are intersubjective relations with other creatures in conserving and protecting the forest (Rossano, 2010; Atran, 2011; Bird-David, 2017; Astor-Aguilera \& Harvey, 2018). Meanwhile, in the SAD's religious tradition or Besale, the SAD and Badewo share (taking and giving). The SAD gives Badewo strength through rituals in the forms of caco, juwadah, red porridge, eggs, incense, and flowers so that Badewo also transfers some power to them, including during a healing process. The SAD understand that this religious ritual is a practice of allegiance between humans and nonhuman beings (Badewo) (Brightman, 1993). This ritual also functions to maintain, reproduce, and recontextualize the reciprocal relationship in social-religious life (Rossano, 2010) and the relationship of sharing and the need for the existence of other beings (Astor-Aguilera, 2010; Astor-Aguilera \& Harvey, 2018). Furthermore, some SAD explained no difference between humans (Bird-David, 2017; Astor-Aguilera \& Harvey, 2018) and nonhuman beings that always interact with the forest. For this reason, the SAD divide forests into 17 categories of traditional and religious spaces (will be elaborated in the next discussion).

However, before elaborating intersubjective relations of forest conservation further, and apart from the discussion of the indigenous religious cosmology of the SAD above, government ecology is a study of the government's awareness of the significance of a sustainable environment (Eblen \& Eblen, 2011; Taylor, 2011; Boyne, 2014; Harrison et al., 2015). It requires the government to recover the earth from global warming and rising sea levels, and other natural disasters. However, in post-reformation Indonesia, few regional governments have awareness and orientation towards the importance of sustainable green government (Hoon, 2010). Regional autonomy should provide opportunities for regional heads to practice green and environmentally friendly governments. However, decentralization is used as a means to exploit natural resources, neglecting the sense of propriety and ecological justice.

In 2017, for example, Forest Watch Indonesia found that there were 8.9 million ha of land whose utilization overlapped between forest concession rights (HPH), industrial plantation forests (HTI), oil palm plantations, and mining between 2013 and 2016 (FWI, 2017). In Jambi between 2013 and 2018, 7,856.17 ha of land were granted permits for mining production operation, divided into 17 concessions, and 234,617.72 ha of forest areas were leased for mining surveys/exploration. In addition, there are four nonmining forest area permits, covering an area of 425.06 ha (MoEF, 2018). Ironically, the issuance of the permits resulted in state losses up to IDR50,467 billion.

Thus, to conserve, preserve, and protect sustainable forests, community-based forest management is needed. The paradigm between the indigenous religious cosmology of the SAD and government ecology in the conservation, preservation, and protection of sustainable forests is a meeting point of the ideal model. The two paradigms need to be integrated to form intersubjective relations as a cuttingedge offer to prevent forest destruction and natural disasters. In addition, intersubjective relations are also useful to inform academics that a biocentrism approach is a right model and suitable to realize government ecological practices (Figure 2). Moreover, besides the anthropocentric and holistic approaches (Wasistiono, 2013), the biocentrism paradigm is more appropriate. This is because biocentrism views humans as species, similar to other creatures (nonhumans), interdependent, and do not favor one another (Rud, 2011; Taylor, 2011).

Zoning integration dynamics in the Bukit Duabelas National Park The concept of community-based forest management or community forest was introduced in 1987 at the 8th World Forestry Congress forum in Jakarta. In essence, this movement aimed to fight for recognition of people's and communities' rights neglected in the devolution 


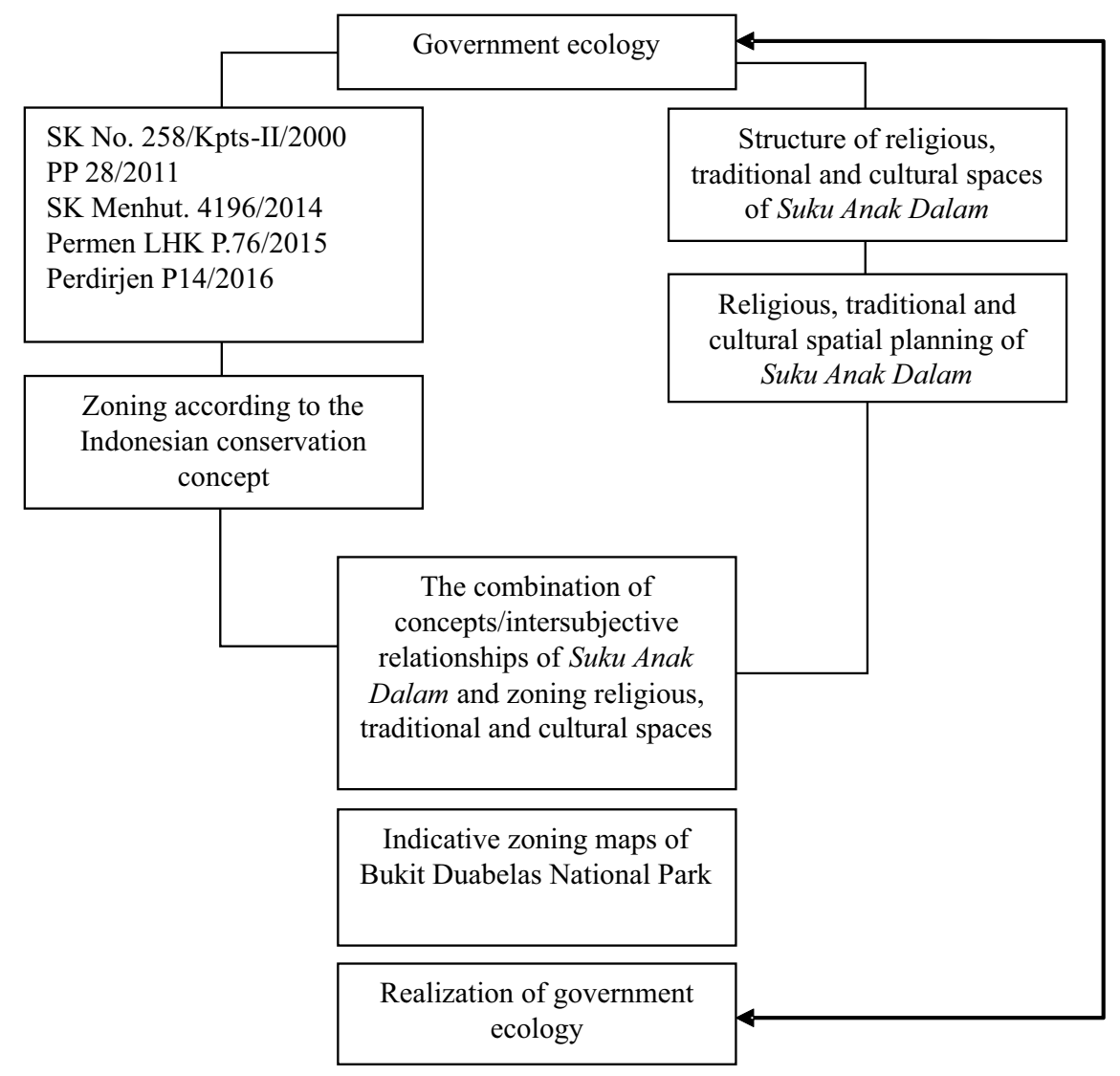

Figure 2 Patterns and cycles of intersubjective relations between government ecology and indigenous religions.

of forest management authority (Moeliono et al., 2010). Thus, the combination of state zoning and indigenous traditional/religious spaces of the SAD can be understood as an alternative way to implement a community-based forest management concept, such as in the Bukit Duabelas, a national park and a circulation area for the SAD. The Bukit Duabelas National Park (TNBD) has an area of 60,500 ha which occupies three regencies: Batanghari with an area of $65 \%$ or 37,000 ha, Sarolangun with an area of $15 \%$ or 9,000 ha, and Tebo with an area of $20 \%$ or 11,500 ha (Yusuf \& Syafrial, 2019). The TNBD ecological area division is based on the Ministry of Forestry Decree Number 258/KptsII/2000, which expanded the area to 60,500 ha. The decision also divided the TNBD area into four territories, namely: 20,700 ha of limited production forest, 11,400 ha of production forest, another 1,200 ha of land-use area, and 27,200 ha of SAD's nature conservation and biosphere reserves (Bakker \& Moniaga, 2010). Previously, the TNBD was a community forest proposed by the Regent of Sarolangun to be a protected forest and biosphere reserve to protect the culture and spaces of the local SAD community.

Nevertheless, since the change of status from Bukit Duabelas to the TNBD, the SAD believes that the government has not accommodated their religious and cultural spaces. Such an assumption stems from the TNBD zoning agreement in 2005, where the interpretation of Law
Number 14 of 1999 concerning forestry and ministry of Forestry Regulation Number P.56/Menhut-II/2006 concerning national park zonation guidelines divided forests into a core zone, forest zone, rehabilitation zone, and utilization zone (Yusuf \& Syafrial, 2019). This zone division has not accommodated or even eliminated their traditional/religious spaces (Table 1). On the other hand, the TNBD office argues that SAD's customary/religious spaces cannot be integrated into state zonation.

The SAD has consistently rejected the decision. Besides doing protests delivering an objection note, the SAD also clashes with the TNBD office. For example, in November 2005, the TNBD office staff banned the SAD of the Sungai Keruh group from entering and crossing the TNBD forest area because they believed the SAD would plant rubber trees in the area (Yusuf \& Syafrial, 2019). The dispute continued to the following year from April to June 2006 that the TNBD office staff banned a group of SAD from starting a plantation in Bukit Suban, an area believed to be a part of the TNBD zone (Yusuf \& Syafrial, 2019).

The debate persisted until 2018 because the SAD and the TNBD Office did not found a solution to the problem. The SAD of the Temenggung Jelitai Mekekal Hulu group (TNBD landscape area), Tebo Regency, submitted an objection note to the Presidential Office of the Republic of Indonesia, which subsequently annulled the 2005 zoning system and revised 
Table 1 Traditional/religious spaces of the SAD in the TNBD landscape

\begin{tabular}{|c|c|c|}
\hline No. & $\begin{array}{l}\text { Traditional/indigenous } \\
\text { religious spaces }\end{array}$ & Explanation \\
\hline 1. & $\begin{array}{l}\text { Tali Bukit (Jungut/Tanoh } \\
\text { Teperuang) }\end{array}$ & $\begin{array}{l}\text { The ridges between Batang Hari River and Tembesi River, from Bukit } \\
\text { Penonton to Bukit Pal (Kleko), Durian Bekampung (Pengusai), Bukit } \\
\text { Mati, Bukit Teregang, and Bukit Duabelas. It is prohibited to start a } \\
\text { plantation in Tali Bukit because its height and steepness exceeds those } \\
\text { in other zones, and it also has springs and functions to prevent } \\
\text { landslides. }\end{array}$ \\
\hline 2. & Bento Benuaron & $\begin{array}{l}\text { Ancestral heritage plantations, farming tradition, is still in practice in } \\
\text { this location until now. }\end{array}$ \\
\hline 3. & Tanah Huma/Pehuma'on & $\begin{array}{l}\text { Areas for farming/agriculture (tanoh huma) is selected based on the } \\
\text { following considerations; an area is flat; the soil is fertile, and; Not in } \\
\text { restricted areas, such as Kleko, Subon, Benteng }\end{array}$ \\
\hline 4. & Benuaron & $\begin{array}{l}\text { Areas covered with forest fruit trees such as durian, rambutan, duku, } \\
\text { rinam, tungau, tampui, bekil, ketopon, kuduk kuya, and others. }\end{array}$ \\
\hline 5. & Tanoh Prana'on/Peranakon & $\begin{array}{l}\text { SAD Women's areas for giving birth and bathing babies. In this perano } \\
\text { land, there are also; Kandong Pusot (plants around the perano land } \\
\text { which must not be disturbed); and Puster Pusot (plants for cutting the } \\
\text { baby's umbilical cord); Jemban Budak (newborn's bathing area). It is } \\
\text { recommended to start a plantation around the perano land, as long as it } \\
\text { does not interfere with sentubung and tenggeris. }\end{array}$ \\
\hline 6. & Tanah Subon/Tanah Bedewo & $\begin{array}{l}\text { It is the land where gods reside according to SAD's belief. This land is } \\
\text { prohibited for cultivation. One example is Bukit Penonton in the } \\
\text { Temenggung Grib area. The forest around Bukit Penonton is still } \\
\text { pristine, and according to the information given by some of the Grib } \\
\text { group members, the location is home to tigers. }\end{array}$ \\
\hline 7. & $\begin{array}{l}\text { Tanoh Balu Balai/Tanoh } \\
\text { Bebalai }\end{array}$ & $\begin{array}{l}\text { It is where the SAD holds wedding ceremonies, and its function is } \\
\text { almost the same as that of Tanoh Ninek Puyang. If one is to start a } \\
\text { huma (plantation), the huma must be away from this land. If not } \\
\text { obeyed, the person will be cursed or keno kelulat (kualat). There are } \\
\text { two kinds of SAD's wedding ceremonies: Balai Nikah and Balai Sangi } \\
\text { (Nazar). }\end{array}$ \\
\hline 8. & $\begin{array}{l}\text { Tanoh Terban/Tebad, Suban, } \\
\text { Tempelanai }\end{array}$ & $\begin{array}{l}\text { Landslides cover rivers. For the SAD, this area is prohibited for } \\
\text { farming because it is considered a Bedewo's home. The Tempelanai } \\
\text { Land is an area that has an invisible guard. }\end{array}$ \\
\hline 9. & Tanoh Nenek Puyang & $\begin{array}{l}\text { Tano Nenek Puyang is relatively the same as the customary forest. The } \\
\text { SAD Makekal Hulu created this area in } 2010 \text { due to an increased } \\
\text { escalation of land clearing conducted by surrounding communities and } \\
\text { palm oil companies, so the SAD took the initiative to create a protected } \\
\text { forest. In addition, Tano Nenek Puyang functions as a place to carry } \\
\text { out traditional ceremonies and religious rituals for the SAD, such as; } \\
\text { giving birth, replanting Senggeris and Sentubung trees, hunting, and a } \\
\text { Badewo's home. }\end{array}$ \\
\hline 10. & Kelaka/Kleko & Kelaka is an old hamlet left by the SAD. It has steep hills. \\
\hline 11. & Benteng & $\begin{array}{l}\text { Benteng is a historic area for the SAD. In the past, Benteng was used } \\
\text { for the defense at war because its landscape is covered with rock and } \\
\text { rarely has large trees. It is also a place of Tano Bedewo and sacred. }\end{array}$ \\
\hline 12. & Bukit Betempo & $\begin{array}{l}\text { This is also a historic place for the SAD because, in the past, it was } \\
\text { used for ironmaking to make kujurs (a spear with a sharp metal tip), } \\
\text { machetes, and others. This region's landscape is hilly and has caves, } \\
\text { and it is the highest point in the Bukit Duabelas area. Bukit Betempoh } \\
\text { is also Tano Bedewo and sacred. }\end{array}$ \\
\hline 13. & Durian Bekampung & $\begin{array}{l}\text { This is a historic land for the SAD. Durian Bekampung was their } \\
\text { ancestral home (ninek puyang). In this location, starting a plantation/ } \\
\text { garden/huma is also forbidden. }\end{array}$ \\
\hline 14. & Tanah Pasoron & $\begin{array}{l}\text { This is a SAD's burial site, which is prohibited for plantation purposes. } \\
\text { In general, Tanoh Pasoron is a pristine forest that is well preserved } \\
\text { because it is rarely entered and crossed by the SAD. }\end{array}$ \\
\hline 15. & $\begin{array}{l}\text { Tengkuruk Sungoi/ } \\
\text { Ngegentingon }\end{array}$ & $\begin{array}{l}\text { This area is in the upstream. The SAD believes that this area is a } \\
\text { Badewo's home. }\end{array}$ \\
\hline
\end{tabular}

Source: Balai TNBD (2019) and Temenggungs Ngerip and Meladang. 
the TNBD zonation. After this process, the debate ended, and on April 18, 2018, the Presidential staff office held a meeting with the TNBD Office and Temenggung representatives to seek ideal governance of the TNBD. On 30 April and 12 May 2018, the first and second dialogs were held to seek an agreement on integrating the SAD's customary/religious spaces concept and state zonation and implementation of a joint survey in the SAD's 13 traditional territories. Eventually, on December 13, 2018, a revised zonation draft was presented, and on May 20, 2019, the latest zonation was endorsed by the Ministry of Environment and Forestry (Balai TNBD, 2019).

\section{Government ecology and indigenous religion practices in} forest conservation To outline the main argument to answer the research question, this sub-section will present a combination practice between state zonation and the SAD's traditional/religious spaces in forest conservation. In short, this practice is called government ecology embodiment with a biocentrism paradigm approach.

Accordingly, this zonation combination, if linked to the government ecology concept (Wasistiono, 2013; Purnomo et al., 2016), is a manifestation of the government's political will towards the conservation, preservation, and protection of sustainable forests (FAO, 2011; Li et al., 2012; Shaheed \& Chowdhury, 2014; Siry et al., 2015; Rahmah et al., 2016) which is in collaboration with indigenous religions to establish intersubjective relations (Maarif, 2015; Cox, 2016; Jenkins et al., 2016). In addition, this combination also elaborates the concept of the regulatory framework, governance arrangement, and tenure (FAO, 2011), which some scientists call green governance (Healy, 2019; Perreault et al., 2015; Purnomo et al., 2016; Springate-
Baginski \& Blaikie, 2013; Wasistiono, 2013; West, 2016). This integration is agreed by the SAD and the government and divided into seven regional categories to accommodate seventeen traditional and religious spaces, namely:

Tali Bukit (Jungut/Tanoh Teperuang) or the core zone This traditional and religious space is a SAD's trek range whose topography is hilly and steep that their customary and religious provisions forbid them from opening and cultivating the area because it functions as a water source and as a TNBD landscape. This is also in line with the national park's core zone concept (Figure 3), which is forest space as something that must not and is not permitted to change (to reduce, eliminate functions, and add nonnative plants and animals).

Our religion and customs forbid the opening of umo (plantations) in the Tali Bukit area because it is a water source. We rely solely on river water for our daily needs. If the area is opened, water springs will automatically dry up. Therefore our customs and religion forbid us from opening it (Temenggung Ngerip and Meladang, interview, 26 November 2019).

This zone is a fundamental zone consisting of 7 areas. According to TNBD Office, this zone is the most protected area that cannot change plants or animals (Interview with Haidir, S.Hut, M.Si on December 2, 2019).

In addition, this area is a SAD's route to go in and out of the TNBD. It has been recorded that two groups often cross the area. They are Temenggung Babayang, who live in Asahan and Hulu Ae Behan, and Temenggung

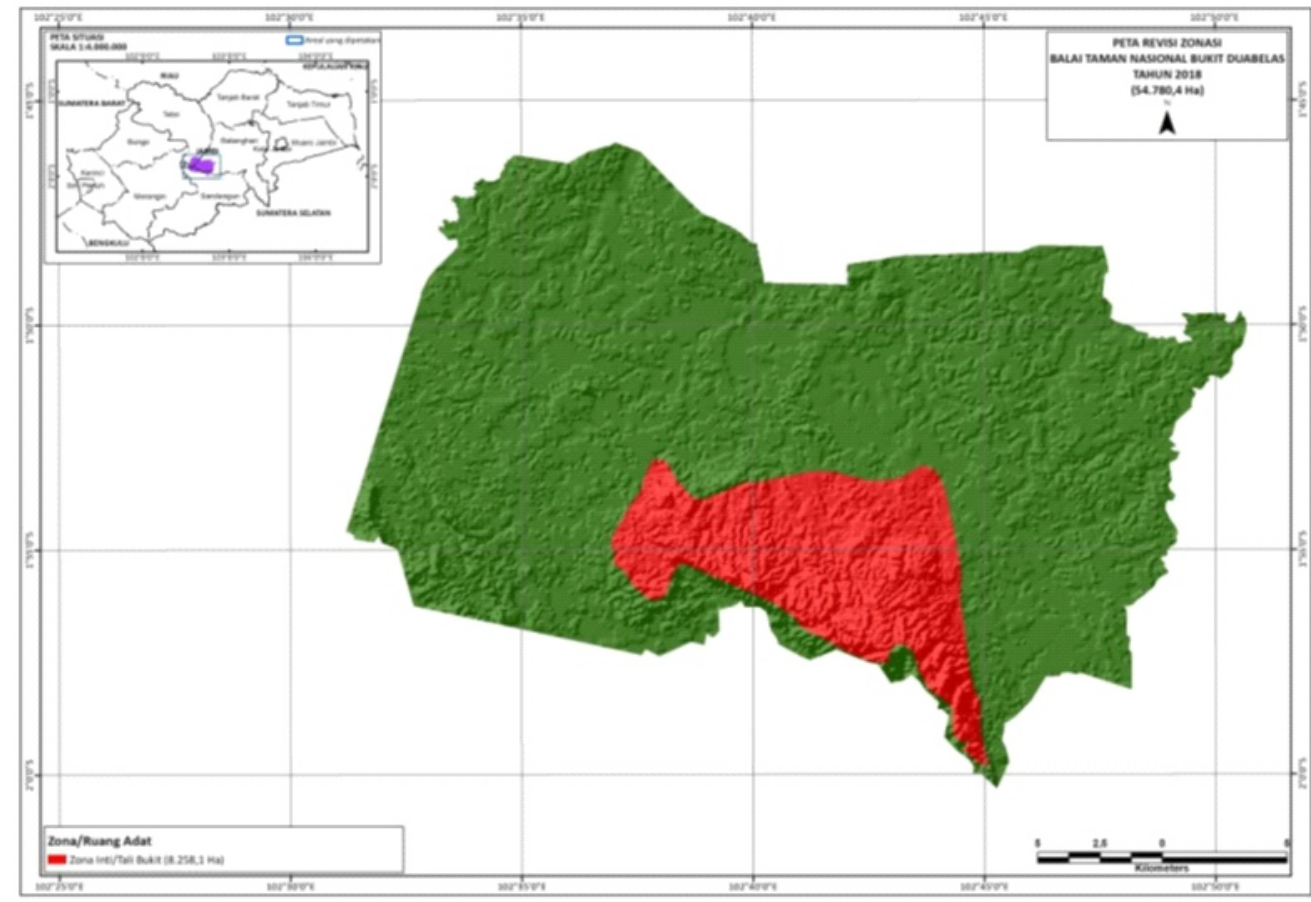

Figure 3 Map of core zone/Tali Bukit/Jungut/Tanoh Teperuang (Balai TNBD, 2019). 
Meladang, who live around the Kejasung Besar River area and along the Jernang River. The core zone, or Tanoh Teperuang, has forest resources, such as dragon's blood, rattans, beehives, and resin (Rahmah et al., 2016). Its vegetation is also still intact, which is a primary forest dominated by meranti (Dipterocarpaceae) trees and the other two types that are critically endangered (Parashores lucida) and endangered (Shorea leprosula). There are also some protected primates and mammals, such as the siamang (Hylobabates syndactylus), gibbons (Presbytis melalophos), honey bears (Helarctos malayanus), tapirs (Tapirus indicus), and napus (Tragalus napu) (Balai TNBD, 2019).

Forest zone/Rimbo Bungaron/Tengkuruk Sungoi/Ngengentingon This zone is a buffer zone or the Tali Bukit protection area, with an area of 1,804,5 ha, an altitude between $75-100 \mathrm{~m}$ above sea level, and a slope of $8-40 \%$. This zone is a tropical rainforest region. Its average temperature is $23-40^{\circ} \mathrm{C}$, with a relative humidity of $80-94 \%$.

Based on SAD's beliefs, since a long time ago, Ninek Puyang (the ancestor of SAD) forbade opening this area because it is perceived as the sources of SAD's livelihood Jernang fruit, rattan, and resin. Besides, this zone is also recognized as the upstream of all river flows in TNBD, which becomes SAD's water sources (Interview with Jenang Jalal, 27 November 2019).

This area is almost the same as the core zone (Figure 4), which is overgrown by various meranti, tampu, balam, kempas, jelutong, tunom, tayoi, ipuh, and cengkuang trees. Besides, this area is a part of the core zone's wildlife range, such as mouse deer, deer, great argus, boars, deer, bears, siamang, hornbills, hedgehogs, pangolins, and others (Balai TNBD, 2019).

This area is the same as Tali Bukit, there is no difference. We call it Rimbo Bungaron (Temenggung Ngerip and Meladang, interview, 26 November 2019).

Utilization zone/Benuaron/Talun This region has 645.3 ha, with an altitude between $25-75 \mathrm{~m}$ above sea level, the slope variation is $0-15 \%$, the average annual rainfall is $3.29-3.67$ $\mathrm{mm}$, the average temperature is between $32-40{ }^{\circ} \mathrm{C}$, and humidity is $80-94 \%$. This area is part of the national park that can be developed into a tourist attraction with a concept of biodiversity and indigenous customs.

Benuaron or Talun is where we build our houses in the forest, and in here there are also natural phenomena that are good for tourism. Pematang Kabau, Bukit Suban, Jernih, and Lubuk Jering have many tourist attractions. That is why we call it the Benuaron land. We also grow plants in this area. (Temenggung Ngerip and Meladang, interview, 26 November 2019).

Thus, four regions have such a potential: Pematang Kabau offers traditional tourism allowing guests to stay in SAD's traditional house and see and participate in their traditional cultural activities (Figure 5). Bukit Suban, Jernih, and Lubuk Jering have a waterfall potential, used for landscape tours, photography, and outdoor camping grounds. In this zone, trees such as meranti, durian, tampui, balam, kempas, jelutung are also found, and there are bears, siamang, and other reptiles. The SAD also utilize forest resources in this zone, such as benuaron (fruit), bambing sialang (forest

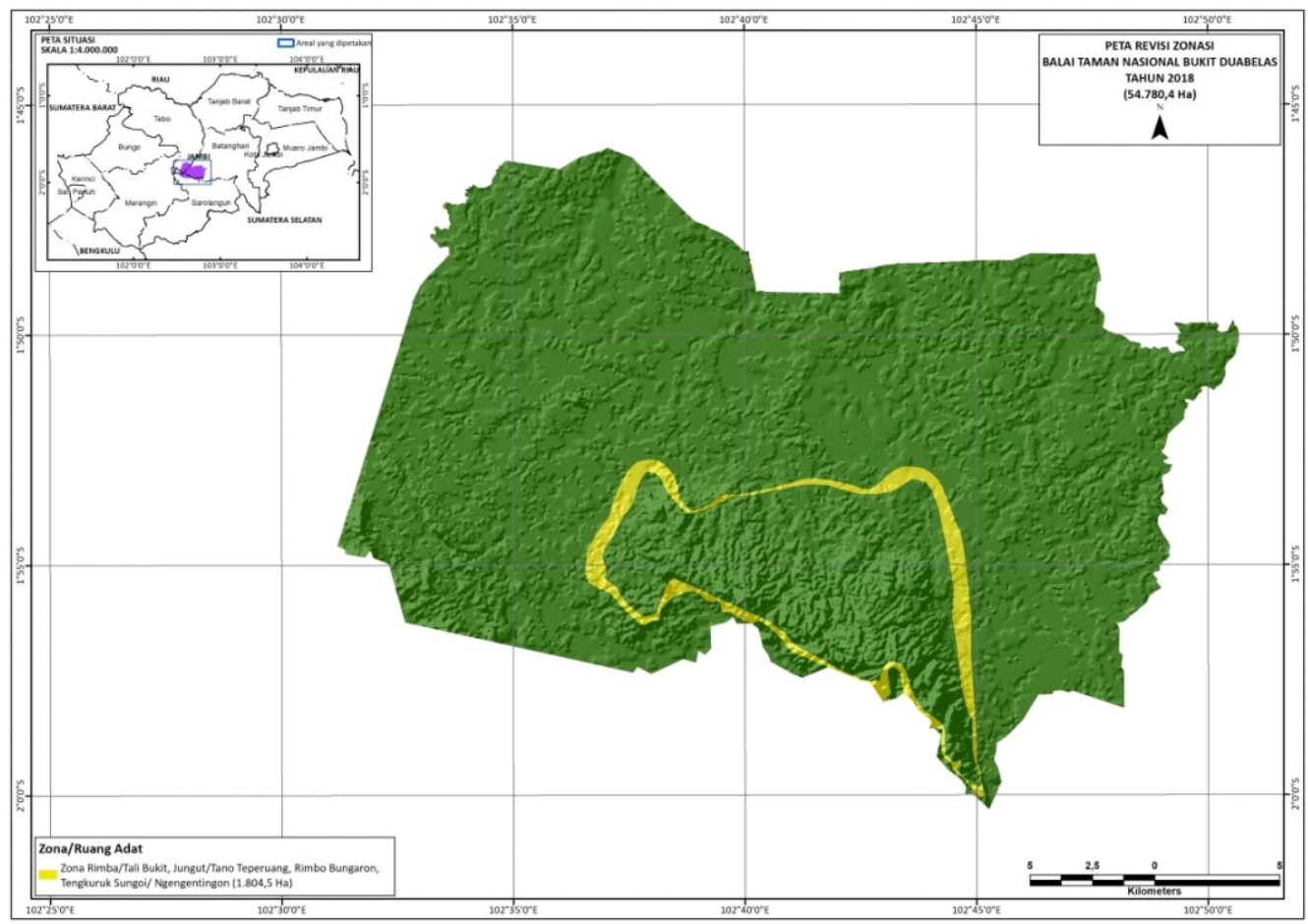

Figure 4 Map of forest zone Rimbo Bungaron (Balai TNBD, 2019). 


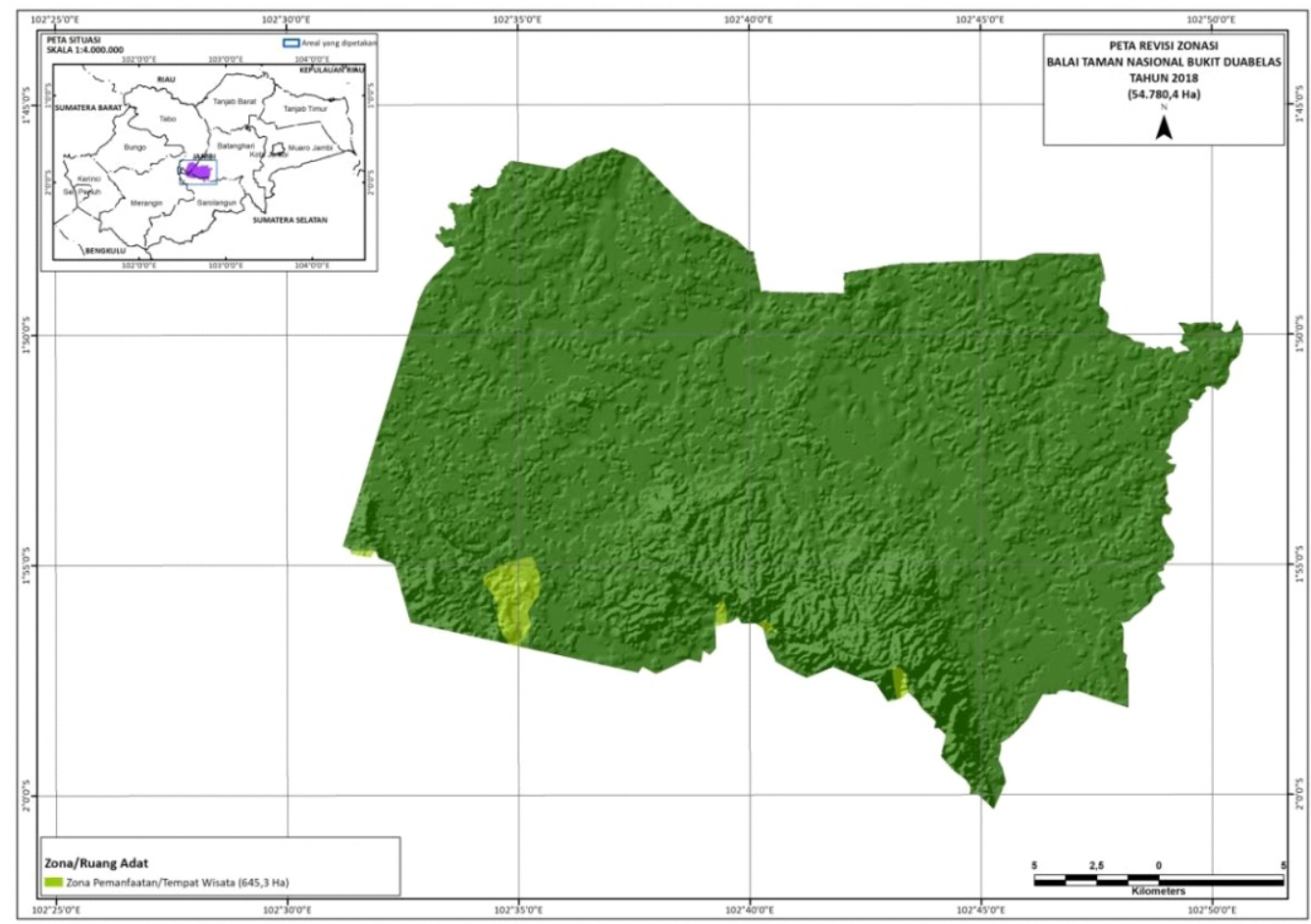

Figure 5 Map of utilization zone/Benuaron/Talun (Balai TNBD, 2019).

honey), Agathis dammara, and others (Balai TNBD, 2019).

Substantively, this area is a defense zone as the same as the Tali Bukit zone. Trees and animals that lived here are also the same as Tali Bukit. However, according to SAD's belief, this zone is a sacred place (Haidir, S.Hut, M.Si, interview, 02 December 2019).

Traditional zone This zone has an area of $36,810.7$ ha with an altitude of $25-75 \mathrm{~m}$ above sea level, slope variation of $0-15 \%$, and an average annual rainfall of $3.29-3.67 \mathrm{~mm}$. The temperature is $32-40{ }^{\circ} \mathrm{C}$, with $80-94 \%$ humidity (Balai TNBD, 2019).

This zone is part of the TNBD, which is divided into two management sections. First is a SAD's traditional zone/tano behuma (Figure 6), namely the forest area used by the SAD for traditional farming to meet basic needs with the principle of nature conservation (Jenang Jalal, Temenggung Ngerip and Meladang, interview, 26 November 2019). Second is the local community's traditional zone, an area used by the surrounding community for farming (Figure 7). Its management is based on the principle of environmental sustainability. Different kinds of trees are planted there, such as rubber trees, durian, cempedak, badaro, tampui, rambai, and others (Balai TNBD, 2019).

Cultural and historical zones/Tano Terban/Suban/Tempelanai/Tano Nenek Puyang/Kelaka/Benteng/ Bukit Betempo/Tano Pasoron/Tano Bedewo/Tano Bebalai This zone is part of the national park $(5,113.4 \mathrm{ha})$, devoted to religious and other sacred activities, with the principle of sustainability. Besides for worship purposes, this area is also for research, education, and preservation of cultural and religious customs such as wedding ceremonies, bedeki, corpse storing, and others (Balai TNBD, 2019).

This zone is a place where SAD performs a religious ritual. It is indeed a special place for SAD's ritual in order to protect the forest. (Interview with Jenang Jalal and Haidir, S.Hut, M.Si on 26 November and 2 December 2019).

For the SAD, this area is called Tano Terban, Suban, Tano Grandma Puyang, Tano Badewo, or Tano Bebalai. While the names are varied, the SAD this area remains a place for worship and religious activities (Figure 8).

We call this area by different names. Some call it Tano Terban, Suban, Tano Grandma Puyang, Tano Badewo, or Tano Bebalai. However, this area is where we conduct worship and other religious activities. For the local community, it is a place of prayer or a mosque. However, in this area, there are no buildings. The area is where we meet or pray to our Lord (Temenggung Ngerip and Meladang, interview, 26 November 2019).

Rehabilitation zone This zone is part of the national park that has been destroyed due to human activities and natural disasters (Figure 9). This zone has 179.7 ha with an altitude of $25-75 \mathrm{~m}$ above sea level and has a $0-15 \%$ slope. The average rainfall is $3.293 .67 \mathrm{~mm}_{\text {year }}{ }^{-1}$. The temperature ranges between $32-40{ }^{\circ} \mathrm{C}$ with humidity of $80-94 \%$ (Balai TNBD, 2019). 


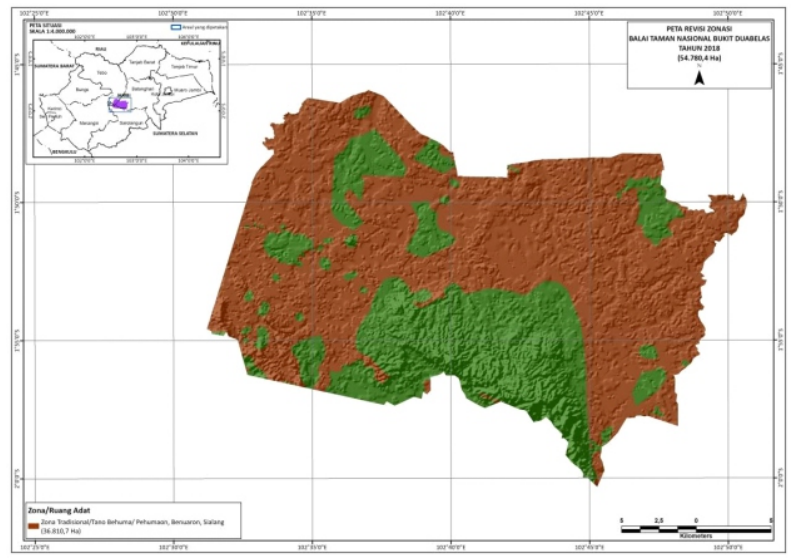

Figure 6 Map of indigenous community's traditional zone/SAD's Tano Behuma (Balai TNBD, 2019).

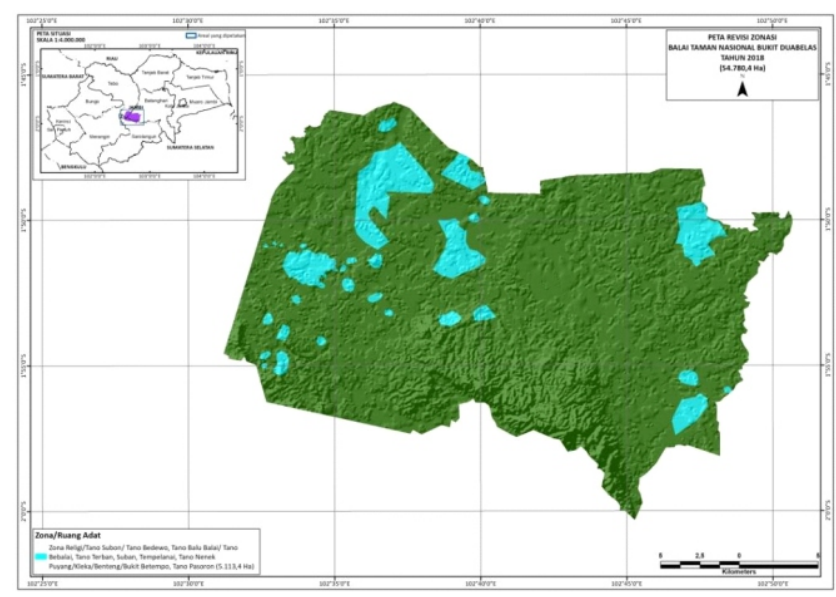

Figure 8 Map of cultural and historical zones.

The forest in this area has mostly been cleared. The forestry office calls it a rehabilitation zone. We are thankful to the office rehabilitating this area. It is a treasure for our children and grandchildren (Temenggung Ngerip and Meladang, interview, 26 November 2019).

This zone is truly a rehabilitation zone. The TNBD Office cannot run this program without SAD's assistance to monitor the rehabilitated forest development. (Interview with Haidir, S.Hut, M.Si, 2 December 2019).

Therefore, the six regional categories and the SAD's 17 traditional and religious spaces above can be simplified in Table 2 .

\section{Conclusion}

SAD and nonhuman beings (forest, land, trees, animals, and badewo) have the same cosmology. Both are bound in a mutual relationship (asking and giving) or a so-called socioreligious relationship. SAD believes that this sharing culture (socio-religious relationship) becomes the only way to meet

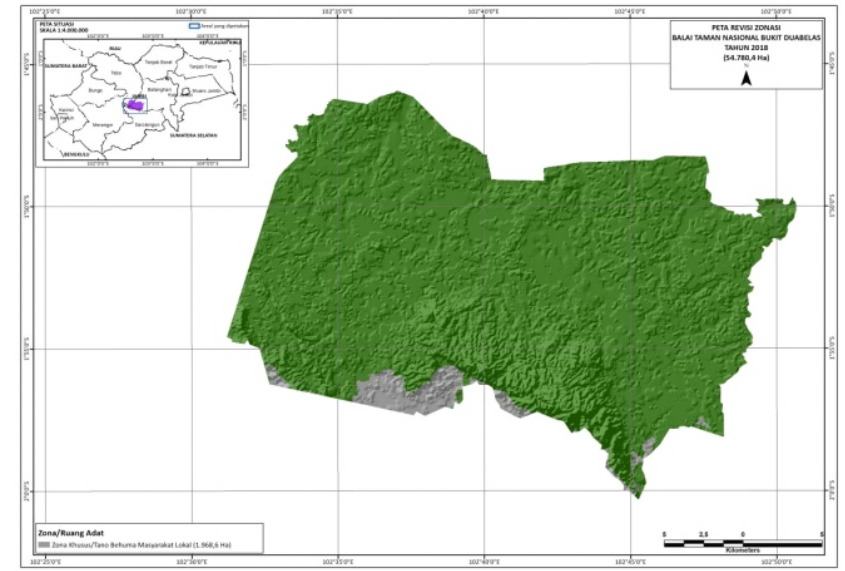

Figure 7 Map of local communities' traditional zones (Balai TNBD, 2019).

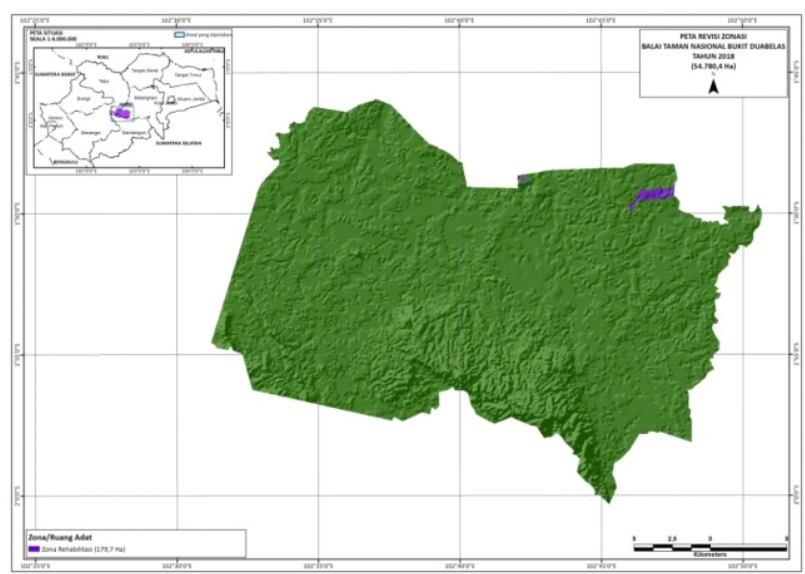

Figure 9 Map of rehabilitation zone (Balai TNBD, 2019).

God (called bersale). Badewo is categorized as a generous character of nonhuman beings species that always inhabit indigenous and religious forest space or known as Tano Badewo and Tano Suban/Tano Tempelanai. Badewo is also believed as a guardian and a re-creator of forest life, which is regarded as an actor of socio-religious relationships in protecting the TNBD forest's biodiversity. Since the status alteration of Bukit Duabelas status to be TNBD, SAD believes that the government has not accommodated and assigned their indigenous religious space into protected national park zone. Hence, SAD has always been striving to ensure that the customary-religious spaces could be recognized and protected. Therefore, on April 18, 2018, the Office of the Presidential staff of the Republic of Indonesia received a memorandum of objection and annulled the 2005 TNBD zoning system to be revised to integrate SAD's customary religious space. From that memorandum of understanding, an intersubjective relationship between SAD's indigenous religions and the ecology of government was created to preserve, maintain, and 


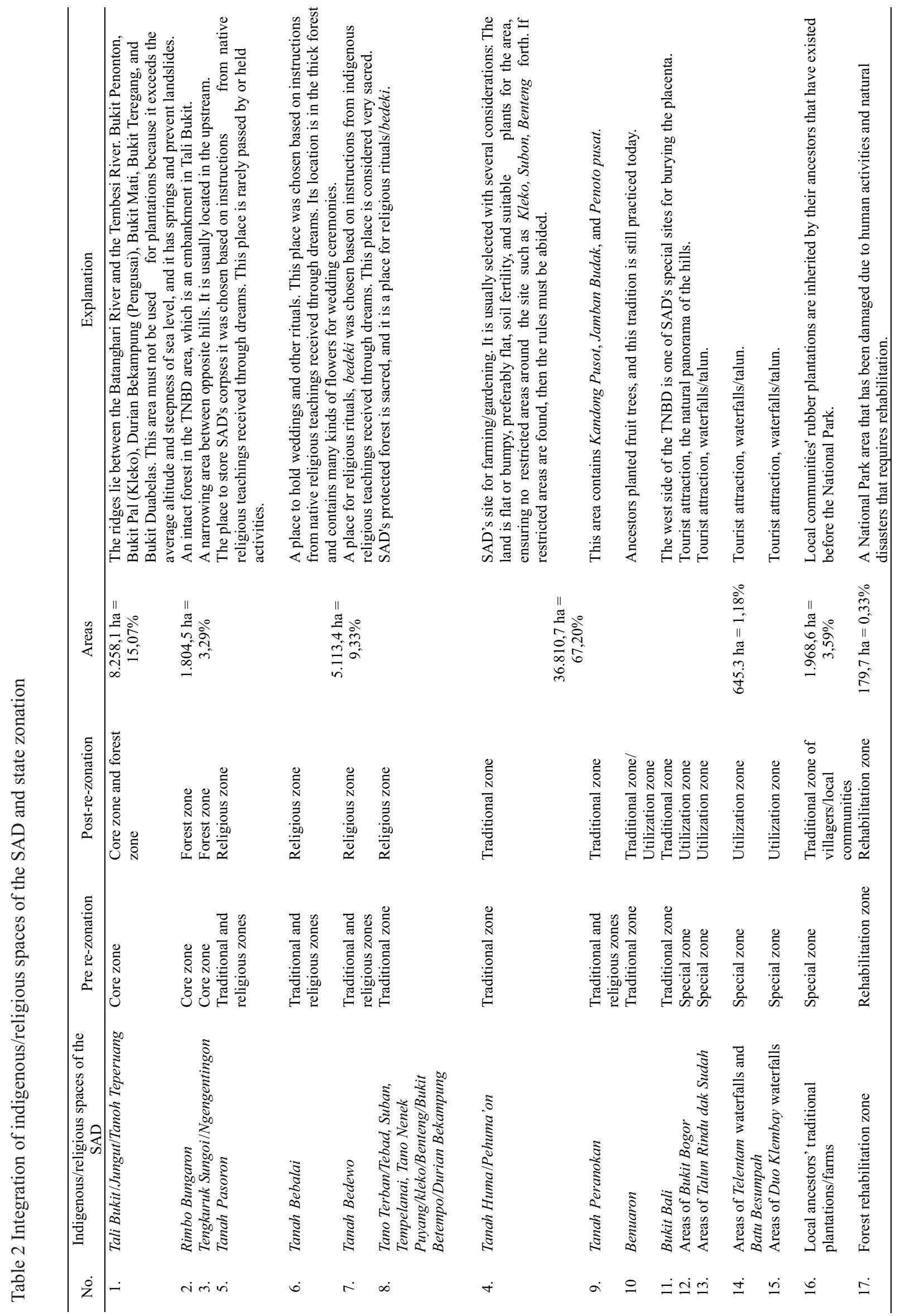


protect sustainable forests. As a living organism entity with an external environment, the government requires to form an intersubjective relationship to actualize the government ecology by integrating indigenous religious-customary spaces that are integrated with forest and nature. This paradigm combination can be understood as an offer to prevent forest destruction and natural disasters through a biocentrism approach. Humans are seen as a species as equal to nonhuman beings, in which they truly need one each other. Thus, this approach can also be referred to as green government practices, which elaborate on the regulatory framework's concepts, governance arrangement, and tenure.

\section{Acknowledgment}

I would like to extend my sincere gratitude and express the highest appreciation to Ahmad Ali Nurdin, $\mathrm{Ph}$. D for his assistance in correcting this article, so it was finished well. I would like to thank Edi Kurniawan, M. Phil, for his valuable comments and proofreading the draft. Also, for Muhammad Beni Saputra, M.A as a translator.

\section{References}

Adansikou, K., Kokou-Kpolou, K., Mbassa Menick, D., \& Moukouta, C. S. (2017). Influence de la religion dans la somatisation dépressive en Afrique. Annales MedicoPsychologiques, 175(6), 536-540. https://doi.org/ 10.1016/j.amp.2015.10.031

Andaya, L. (2002). Orang asli and Melayu relations: A crossborder perspective. Antropologi Indonesia, 67. https://doi.org/10.7454/ai.v0i67.3428

Andaya, L. Y. (2001). The search for the 'Origins' of Melayu. Journal of Southeast Asian Studies, 32(3), 315-330. https://doi.org/10.1017/s0022463401000169

Anderbeck, K. R. (2003). Malay dialects of the Batanghari River Basin (Jambi, Sumatra). SIL International.

Astor-Aguilera, M. A. (2010). The Maya world of communicating objects: Quadripartite crosses, trees, and stones. New Mexico: University of New Mexico Press.

Astor-Aguilera, M., \& Harvey, G. (Eds.). (2018). Rethinking relations and animism. London: Routledge. https://doi.org/10.4324/9780203709887

Atran, S. (2011). In Gods we trust: The evolutionary landscape of religion. Oxford: Oxford University Press. https://doi.org/10.1093/acprof:oso/9780195178036.001. 0001

Bakker, L., \& Moniaga, S. (2010). The space between: Land claims and the law in Indonesia. Asian Journal of Social Science, 38(2), 187-203. https://doi.org/10.1163/ $156853110 X 490890$

[Balai TNBD] Balai Taman Nasional Bukit Duabelas. (2019). Zonasiltata ruang adat pengelolaan Taman Nasional Bukit Duabelas Provinsi Jambi. Jambi: Balai Taman Nasional Bukit Duabelas.
Benjamin, J. (2013). Shadow of the other intersubjectivity and gender in psychoanalysis. London: Routledge. https://doi.org/10.4324/9780203948149

Benjamin, J. (2017). Beyond doer and done to recognition theory, intersubjectivity and the third. London: Routledge. https://doi.org/10.4324/9781315437699

Berta,A. E. V. (2014). People of the jungle: Adat, women and change among Orang Rimba. Oslo: University of Oslo. Retrieved from http://hdl.handle.net/10852/40458

Bird-David, N. (2017). Us, relatives: Scaling and plural life in a forager world. California: University of California Press. https://doi.org/10.1525/california/97805202 93403.001.0001

Boyne, R. (2014). The future: Six drivers of global change by Al Gore. Theory, Culture \& Society, 31(6), 151-155. https://doi.org/10.1177/0263276414536236

Brightman, R. A. (1993). Grateful prey: Rock cree humananimal relationships. California: University of California Press. https://doi.org/10.2307/970221

Charmaz, K. (2014). Constructing grounded theory. London: SAGE Publications Ltd.

Childs, J. R., \& Hicks, C. C. (2019). Securing the blue: Political ecologies of the blue economy in Africa. Journal of Political Ecology, 26(1), 323-340. https://doi.org/10.2458/v26i1.23162

Chowdhury, M. S. H. (Ed.). (2014). Forest conservation in protected areas of Bangladesh. New York: Springer. https://doi.org/10.1007/978-3-319-08147-2

Cox, J. L. (2016). From primitive to indigenous: The academic study of indigenous religions. London: Routledge. https://doi.org/10.4324/9781315583488

Diamond, S. (Ed.). (1960). Culture in history: Essays in honor of Paul Radin. New York: Brandeis University

Eblen, R. A., \& Eblen, W. R. (2011). The encyclopedia of the environment. Boston: Houghton Mifflin Co.

[FAO] Food and Agriculture Organization. (2011). Reforming forest tenure: Issues, principles and process: FAO Forestry Paper No. 165.

Flick, U. (2014). The SAGE handbook of qualitative data analysis. https://doi.org/10.4135/9781446282243

Fricke, C., \& Føllesdal, D. (Eds.). (2012). Intersubjectivity and objectivity in Adam Smith and Edmund Husserl. Berlin, Boston: De Gruyter. https://doi.org/10.1515/ 9783110325942

[FWI] Forest Watch Indonesia. (2017). Silang sengkarut pengelolaan hutan dan lahan di Indonesia. Retrieved from http://fwi.or.id. 
Goldstein, L. F. (1962). Culture in history: Essays in honor of Paul Radin. Stanley Diamond. Philosophy of Science, 29(4), 442-443. https://doi.org/10.1086/287903

Harrison, R. M., Hester, R. E., Chipperfield, M., Broomfield, M., Mason, R., Abdallah, M., ..., \& Taylor, D. (2015). Issues in environmental science and technology 40. In R. E. Hester \& R. M. Harrison (Eds.), Still only one Earth: Progress in the 40 years since the first UN Conference on the Environment. Cambridge: Royal Society of Chemistry. https://doi.org/10.1111/sum.12321

Healy, H. (2019). A political ecology of transdisciplinary research. Journal of Political Ecology, 26(1), 500-528. https://doi.org/10.2458/v26i1.23245

Hoon, M. T. (2010). Green growth policy in the Republic of Korea: Its promise and pitfalls. Korea Observer, 41(3), 379-414.

Hunt, S. (Ed.). (2005). Indigenous religions. London: Chelsea House Publishers. https://doi.org/10.4324/ 9781315252407

Husserl, E. (2019). First philosophy. Dordrecht: Springer. https://doi.org/10.1007/978-94-024-1597-1

Japarudin. (2014). Kepercayaan Orang Rimba Jambi terhadap Betetutuh Sang Mesekin. Kontekstualita, 29(1), $15-40$.

Jenkins, W. J., Tucker, M. E., \& Grim, J. (Eds.). (2016). Routledge handbook of religion and ecology. London: Routledge. https://doi.org/10.4324/9781315764788

Li, C., Lafortezza, R., \& Chen, J. (2012). Landscape ecology in forest management and conservation: Challenges and solutions for global change. Choice Reviews Online, 49(05), 492647. https://doi.org/10.5860/choice.49-2647

Maarif, S. (2015). Ammatoan indigenous religion and forest conservation. Worldviews: Environment, Culture, Religion, 19(2), 144-160. https://doi.org/10.1163/15685 357-01902005

Mailinar, \& Nurdin, B. (2013). Kehidupan keagamaan Suku Anak Dalam di Dusun Senami III Desa Jebak Kabupaten Batanghari Jambi. Kontekstualita, 28(2), 247-271.

Marcel, G. (1950). The mystery of being. London: The Harvill Press Ltd.

Marcel, G. (2007). Being and having. Glasgow: Marcel Press.

Marcel, G., \& Hanley, K. R. (2004). Ghostly mysteries: A mystery of love and the posthumous joke. Milwaukee: Marquette Univ Press.

Masy'ud, B., Felayati, N. R., \& Sunarminto, T. (2020). Local wisdom in animal conservation and animal use as medicine of orang rimba in Bukit Duabelas National Park, Jambi. Jurnal Manajemen Hutan Tropika, 26(1),
72-79. https://doi.org/10.7226/jtfm.26.1.72

[MoEF] Minitry of Environment and Forestry. (2018). Statistik lingkungan hidup dan kehutanan Tahun 2018. Retrieved from http://www.menlhk.go.id.

Moeliono, Limberg, M., Minnigh, G., Mulyana, P., Indriatmoko, A., Utomo, Y., ..., \& Purwanto, R. (2010). Meretas kebuntuan: Konsep dan panduan pengembangan zona khusus bagi taman nasional di Indonesia. Bogor: CIFOR.

Moeliono, M., Thuy, P. T., Bong, I. W., Wong, G. Y., \& Brockhaus, M. (2017). Social forestry-why and for whom? A comparison of policies in Vietnam and Indonesia. Forest and Society, 1(2), 1. https://doi.org/ 10.24259/fs.v1i2.2484

Montgomery, E. J. (2019). Religion and faith in Africa: Confessions of an animist by Agbonkhianmeghe E. Orabotor. Journal of Ecumenical Studies, 54(2), 295-297.https://doi.org/10.1353/ecu.2019.0020

Olson, K., Young, R. A., \& Schultz, I. Z. (2016). Handbook of qualitative health research for evidence-based practice. New York: Springer International Publishing. https://doi.org/10.1007/978-1-4939-2920-7

Perreault, T., Bridge, G., \& McCarthy, J. (Eds.). (2015). The routledge handbook of political ecology. London: Routledge. https://doi.org/10.4324/9781315759289

Peterson, D. J. (2012). God and the new atheism: A critical response to Dawkins, Harris, and Hitchens by John F. Haught. Dialog, 51(3), 254-256. https://doi.org/10.11 $11 /$ j.1540-6385.2012.00694.x

Prasetijo, A. (2013). Behind the forest: The ethnic identity of Orang Kubu (Orang Rimba), Jambi-Indonesia. 10th Conference on Hunting and Gathering Societies, 2008, $1-16$.

Prasetijo, A. (2015). Orang Rimba, true custodian of the forest: Alternative strategies and actions in social movement against hegemony. Indonesia Center for Sustainable Development \& Komunitas Konservasi Indonesia.

Prasetijo, A. (2017a). Livelihood transformations of the Orang Rimba as tacit resistance in the context of deforestation. Endogami: Jurnal Ilmiah Kajian Antropologi, 1(1), 1. https://doi.org/10.14710/ endogami. 1.1.1-13

Prasetijo, A. (2017b). Living without the forest: Adaptive strategy of Orang Rimba. Senri Ethnological Studies, 95, 255-278. https://doi.org/10.15021/00008586

Purnomo, E. P., Nurmandi, A., Sulaksono, T., Hidayati, M., Ramdani, R., \& Agustiyara. (2016). Ekologi pemerintahan tata kelola dan kelembaman birokrasi dalam menangani kebakaran hutan, pengelolaan sawit, serta peranan elit lokal. Yogyakarta: LP3M UMY. 
Rahmah, R., Kartawinata, K., Nisyawati, N., Wardhana, W., $\&$ Nurdin, E. (2016). Tree species diversity in the lowland forest of the core zone of the Bukit Duabelas National Park, Jambi, Indonesia. REINWARDTIA, 15(1), 11. https://doi.org/10.14203/reinwardtia.v15i1.2440

Rossano, M. J. (2010). Supernatural selection: How religion evolved. Oxford: Oxford University Press. https://doi.org/10.1093/acprof:oso/9780195385816.001. 0001

Rud, A. G. (2011). Albert Schweitzer's legacy for education: Reverence for life. Palgrave Macmillan. https://doi.org/ $10.1057 / 9780230116238$

Sager, S. (2008). The sky is our roof, the earth our floor: Orang rimba customs and religion in the Bukit Duabelas region of Jambi, Sumatra [disstertation]. Cannbera: The Australian National University.

Sager, S. (2017). The stalk that supports the flower: Orang rimba kinship, marriage and gender in Jambi Sumatra. Oceania, 87(1), 78-95. https://doi.org/10.1002/ ocea.5149

Saldaña, J. (2012). The coding manual for qualitative researchers. London and New York: SAGE Publications.

Shoko, T. (2016). Karanga indigenous religion in Zimbabwe: Health and well-being. In Karanga Indigenous Religion in Zimbabwe: Health and Well-Being. https://doi.org/10. 4324/9781315590905

Singh, M., Kaptchuk, T. J., \& Henrich, J. (2020). Small gods, rituals, and cooperation: The Mentawai water spirit Sikameinan. Evolution and Human Behavior (in press). https://doi.org/10.1016/j.evolhumbehav.2020.07.008

Siry, J. P., McGinley, K., Cubbage, F. W., \& Bettinger, P. (2015). Forest tenure and sustainable forest management. Open Journal of Forestry, 05(05), 526-545. https://doi.org/10.4236/ojf.2015.55046

Smith, B., \& Sparkes, A. C. (Eds.). (2016). Routledge handbook of qualitative research in sport and exercise. London: Routledge. https://doi.org/10.4324/978131 5762012

Springate-Baginski, O., \& Blaikie, P. (Eds.). (2013). Forests people and power: The political ecology of reform in
South Asia. London: Routledge. https://doi.org/10.4324/ 9781849771399

Takiddin. (2014). Nilai-nilai kearifan budaya lokal Orang Rimba (Studi pada Suku Minoritas Rimba di Kecamatan Air Hitam Provinsi Jambi). Sosio Didaktika: Social Science Education Journal, 1(2). https://doi.org/10. 15408/sd.v1i2.1258

Taylor, P. W. (2011). Respect for nature: A theory of environmental ethics (25th anniversary edition). Princeton: Princeton University Press.

Tremlett, P. F., Harvey, G., \& Sutherland, L. T. (2017). Edward Burnett Tylor, religion and culture. London: Bloomsbury Academic. https://doi.org/10.5040/ 9781350003446

Tylor, E. B. (2016). Primitive culture. New York: Dover Publications.

Tymieniecka, A.-T. (2014). Phenomenology of space and time: The forces of the cosmos and the ontopoietic genesis of life. Book One. New York: Springer International Publishing.

Wasistiono, S. (2013). Pengantar ekologi pemerintahan. Bandung: IPDN Press.

West, P. (2016). Dispossession and the environment: Rhetoric and inequality in Papua New Guinea. New York: Columbia University Press. https://doi.org/10.7312/west 17878

Wicks, D. (2017). The coding manual for qualitative researchers. Qualitative Research in Organizations and Management: An International Journal, 12(2), 169-170. https://doi.org/10.1108/qrom-08-2016-1408

Wright, R. M. (2012). Fixed forms and fluid powers: Intersubjective cosmos and personhood. Anthropology and Humanism, 37(2), 156-176. https://doi.org/10.1111/ j.1548-1409.2012.01126.x

Yusuf, M., \& Syafrial. (2019). A big battle: The state vs. indigenous people (Case study in Jambi Province). Jurnal Ilmu Sosial dan Ilmu Politik, 23(1). https://doi. org/10.22146/jsp.37568 